\title{
A Review of Thermal Comfort Applied in Bus Cabin Environments
}

\author{
Matheus das Neves Almeida $1,2, * \mathbb{C}$, Antonio Augusto de Paula Xavier ${ }^{1}$ \\ and Ariel Orlei Michaloski ${ }^{1}$ (1) \\ 1 Ergonomics Laboratory, Universidade Tecnológica Federal do Paraná (UTFPR), Rua Doutor Washington \\ Subtil Chueire, 330, Jardim Carvalho, Ponta Grossa, Paraná 84017-220, Brazil; \\ augustox@utfpr.edu.br (A.A.d.P.X.); ariel@utfpr.edu.br (A.O.M.) \\ 2 Campus Universitário Ministro Petrônio Portella, Universidade Federal do Piauí (UFPI), Ininga, Teresina, \\ Piauí 64049-550, Brazil \\ * Correspondence: matheusalmeida@ufpi.edu.br
}

Received: 11 November 2020; Accepted: 27 November 2020; Published: 3 December 2020

check for updates

\begin{abstract}
As of 2020, it has been 50 years since the publication of Fanger's predictive model of thermal comfort that was designed for indoor environments and attention worldwide is directed at the COVID-19 pandemic and discussions around recommendations for these indoor environments. In this context, many environments and their occupants will suffer consequences related to thermal comfort due to the necessary indoor air changes. In bus cabins, the impact might be even greater, seeing that they are responsible for the mass transportation of people. Thus, this paper intends to review the studies on thermal comfort that analyzed bus cabin environments. It adapts the PRISMA methodology and, as a result, it includes 22 research papers published in journals. Among those, $73 \%$ focused on approaching the occupants' thermal sensation, followed by fuel/energy economy $(18 \%)$, and driver productivity $(9 \%)$. The current state-of-the-art indicates that air temperature and air velocity were the parameters most employed by the included studies, but eight papers analyzed all six parameters of the standard models of thermal comfort. The most employed model of thermal comfort was Fanger's, but there has not been an investigation that assesses its consistency in predicting the occupants' thermal sensation in the explored environment. Nevertheless, the analyzed studies recommended constant air change inside closed buses or keeping them open to minimize adverse effects on the occupants' health, especially due to airborne diseases and $\mathrm{CO}_{2}$ concentration possibly being a suitable indicator to identify the need for air change.
\end{abstract}

Keywords: thermal comfort; air quality; bus cabins environments; driver and passenger comfort

\section{Introduction}

The city public transportation bus has the purpose of transporting numerous people and is considered a sustainable means of transportation [1-3]. The studies about comfort in buses may encompass the knowledge areas of thermal, acoustic, luminous, vibration, air quality, acceleration, and ergonomic comfort [4,5], and the influence of those areas might reflect on the level of service and the passengers' choice to use this means of transportation [6-8].

In bus cabins, thermal comfort has been regarded as one of the most significant factors for the passengers' comfort level $[9,10]$. Due to high temperatures, the level perceived by the passengers was considered unsatisfactory and described in a field study conducted on buses with air conditioning during the night in China [11]. Moreover, the environmental parameters air temperature, air speed, and mean radiant temperature, considered inputs of standard models of thermal comfort like Fanger's Predicted Mean Vote-Predicted Percentage Dissatisfied (PMV-PPD) [12], and their adverse impacts on 
the passengers' health and well-being have drawn the attention of previous studies [13,14]. The other inputs of the mentioned predictive model are air relative humidity, metabolic rate, and clothing thermal insulation [12].

In fact, the impact generated by studies of this knowledge area in bus cabin environments affects not only passengers, but it also may be correlated with drivers through the approaches of studies on the well-being/health and productivity of these workers and the fuel/energy economy of this means of transportation [15-19].

One relevant aspect approached by this study that will influence the thermal comfort perceived by the occupants of bus cabins, especially if the bus has an air conditioning system, is the need for indoor air change in this environment, due to the cautions with the new coronavirus (SARS-CoV-2) pandemic decreed by the World Health Organization in 2020 [20]. According to Nishiura et al. [21], closed environments contribute to the large-scale transmission of COVID-19, especially secondary transmissions.

Besides the justifications directed at the importance of thermal analyses in bus cabin environments and the need for indoor air change, this investigation pays tribute to the 50 years of the publication of Fanger's PMV-PPD model of thermal comfort [12]. This model is currently the most employed and widespread worldwide $[22,23]$ in terms of predicting the mean vote response of thermal sensation of a large group of people (PMV) exposed to the same thermal environment [24-26], as well as the percentage of people dissatisfied (PPD) with said environment [27]. According to Yao, Li, and Liu [28], the PMV-PPD predictive model was incorporated into ISO standards in the 1980s and is still seen as the basis for the ISO 7730 and ASHRAE 55 standards [25].

However, the search for papers published in journals conducted in the databases Science Direct, Scopus, Spring Link, and Web of Science, with no time restrictions and employing the Preferred Reporting Items for Systematic Reviews and Meta-Analyses (PRISMA) methodology, revealed an absence of review papers that address thermal comfort studies conducted in bus cabin environments. This absence can be seen as a gap in the literature, which this proposal of investigation intends to fill. Therefore, this study can be considered unprecedented, theoretically justified by the lack of review papers in the area.

In this context, this investigation seeks, through a literature review, to identify works that analyzed the questions of thermal comfort/discomfort, be it due to cold or heat, in bus cabins with or without an air conditioning system. To achieve the general objective of this investigation, five questions were formulated and explored in the studies included in this review and focused on the types of approaches taken by these studies on the identification of measurable parameters of thermal comfort that were investigated by them, on the identification of other parameters linked to other types of comfort analyzed along with thermal comfort, in face of the norms that supported or guided the studies, and in the identification of the most used models to evaluate the thermal comfort of the bus cabins.

\section{Materials and Methods}

Having selected the theme, centered on the aspects related to thermal comfort in bus cabin environments, the efforts turned to define the research intention, guided by the following research questions (RQ). This methodological starting point has already been adopted by a thermal comfort study [23].

$\mathrm{RQ}_{1}$ : What were the approaches adopted by thermal comfort studies conducted in bus cabins?

Overall, thermal comfort studies in vehicular environments may adopt approaches in three directions, in isolation, or combinations. The three directions are the thermal satisfaction of passengers and drivers, which can be expressed in terms of well-being, health, and security; productivity, usually linked to the performance of drivers; the fuel/energy conservation of the vehicles [26,29].

$\mathrm{RQ}_{2}$ : What thermal comfort parameters were investigated in the studies that analyzed bus cabins?

The six essential parameters employed by models of thermal comfort are divided into environmental and personal [30-32]. The environmental parameters are air temperature $\left(t_{a}\right)$, air velocity 
$\left(\mathrm{V}_{\mathrm{a}}\right)$, air relative humidity $(\mathrm{UR})$, and mean radiant temperature $\left(\mathrm{t}_{\mathrm{rm}}\right)$, while the personal ones comprise metabolic rate $(\mathrm{M})$ and clothing thermal insulation $\left(\mathrm{I}_{\mathrm{clo}}\right)$ [25,32-34].

$R_{2}$ : Besides thermal comfort parameters, what other variables were analyzed by thermal comfort studies conducted in bus cabins?

$\mathrm{RQ}_{3}$ intends to complement the second research question. As mentioned in the introduction, the comfort perceived by the bus's occupants may encompass other types of comfort other than thermal $[4,5]$.

$\mathrm{RQ}_{4}$ : What international standards of thermal comfort did the studies that analyzed the thermal conditions of bus cabins follow?

The knowledge area of thermal comfort has international standards as guidelines, such as ASHRAE and ISO [35-40]. Moreover, since the thermal environment in question is the bus, there are specific standards of the knowledge area directed at the vehicular environment, such as the ISO 14505 series [41-43].

$\mathrm{RQ}_{5}$ : What standard models of thermal comfort were employed to assess the bus cabins?

A few attempts to generate models of thermal comfort can be found in the literature. However, the standard models for that purpose internationally are commonly PMV-PPD, SET* Adaptive, and Gagge's [37,40].

After defining the research questions, this paper adopted the Preferred Reporting Items for Systematic Reviews and Meta-Analyses (PRISMA) methodology, proposed by Moher et al. [44], through the four stages: identification, triage, selection, and inclusion of works. It is worth mentioning that the software applications Mendeley, JabRef, Microsoft Excel, and R Project with Bibliometrix script [45] were employed as tools in the treatment and analysis of the works in order to generate the bibliometric and quantitative results of this investigation.

The work identification stage was carried out in view of the two thematic axes previously mentioned (thermal comfort and bus), which were translated by the keywords of Table 1 .

Table 1. Keywords employed in the identification stage of the method adopted.

\begin{tabular}{ccc}
\hline Keywords & Operator & Keywords \\
\hline & & $\begin{array}{c}\text { Predicted Percentage Dissatisfied (PPD) } \\
\text { Pus }\end{array}$ \\
& AND & Predicted Mean Vote (PMV) \\
& Thermal Comfort \\
& Thermal Discomfort \\
\hline
\end{tabular}

In Table 1, it is possible to observe the columns with the keywords of the two mentioned thematic axes. The first refers to the thermal environment to be explored and the third concerns the expression and variants of the thematic axis thermal comfort.

Besides the Boolean operator AND, employed to combine the keywords from the two columns in Table 1, this investigation utilized OR between the words from the third column. Thus, the final combination was denoted by the following expression: "bus" AND ("PPD" OR "PMV" OR "Predicted Percentage Dissatisfied" OR "Predicted Mean Vote" OR "thermal comfort" OR "thermal discomfort"). Afterward, a search was conducted in the databases Science Direct, Scopus, Springer Link, and Web of Science up to 17 October 2020, with no time restrictions.

After stage 1, the triage stage was conceived having as reference the criteria of work inclusion and exclusion presented in Table 2.

While acknowledging the importance of the other sources of origin of the papers or no attempt to discourage researchers to disseminate their research into other means without a journal, as well as writing articles in languages other than English, the criteria in Table 2 were idealized based on a set of factors considered to have the greatest impact on the choice of academic works and also to sort 
the studies sought. After the triage of the works, the review focused on the selection of research and review papers, which underwent the selection process (stage 3).

Table 2. Inclusion and exclusion criteria employed in the triage stage of the method adopted.

\begin{tabular}{cc}
\hline Inclusion Criteria & Exclusion Criteria \\
\hline Review and research papers & Papers that do not research and review papers \\
\hline Papers in English & Papers in other languages \\
& Papers that do not contain citation information (author names, title, and year) \\
\hline Papers published until 2020 & Duplicated papers \\
\hline
\end{tabular}

The selection stage determined the eligibility criterion, which centered on papers within the scope (thermal comfort and bus cabins environments), in other words, we selected papers that investigated certain parameters of thermal comfort inside buses. The criterion was verified through reading the title, abstract, and keywords of the research papers that passed the triage stage.

Finally, the stage of inclusion of papers (stage 4) that constituted the final portfolio of this review was conducted. Thus, this stage included the papers that were found on Google Scholar and that cited the papers that passed the eligibility stage.

The limitations of this study are related to the methodology in two central points: the choice of literature databases, restricted to Science Direct, Scopus, Springer Link, and Web of Science, and the selection of works to be analyzed as review and research papers were prioritized to compose the introduction and result/discussion sections, respectively.

\section{Results}

The results achieved by this investigation were divided into two subsections: while the first exposes the quantitative result showing the values of each step of the review method through tables and figures; the second shows a bibliometric indicating the publication trends of these two themes together over the years, the renowned authors, the most used keywords in the studies, and the journals in which they were published.

\subsection{Quantitative Results}

The application of the systematic literature review method adopted by this study returned the preliminary result of the number of works, presented in Table 3.

Table 3. Preliminary result of the review of thermal comfort in buses per database.

\begin{tabular}{ccccc}
\hline \multirow{2}{*}{ Documents Type } & \multicolumn{4}{c}{ Databases } \\
\cline { 2 - 5 } & Science Direct & Scopus & Springer Link & Web of Science \\
\hline Review papers & 0 & 0 & 0 & 0 \\
Research papers & 18 & 40 & 349 & 31 \\
Conference papers & 0 & 42 & 77 & 9 \\
Others * $^{*}$ & 2 & 0 & 599 & 1 \\
\hline Total & $\mathbf{2 0}$ & $\mathbf{8 2}$ & $\mathbf{9 4 8}$ & $\mathbf{4 1}$ \\
\hline
\end{tabular}

* Others were: books, book chapter, meeting, protocol, letter. 
According to Table 3, no review papers approaching both aspects (thermal comfort and bus cabin environments) simultaneously were published in a journal. Therefore, it is possible to state that this investigation is unprecedented.

Moreover, it is possible to observe that the Springer Link database returned, at first, the highest number of papers, followed by Scopus, Web of Science, and Science Direct, respectively. Figure 1 summarizes the results of each stage conducted to obtain the answers for the RQ's formulated.

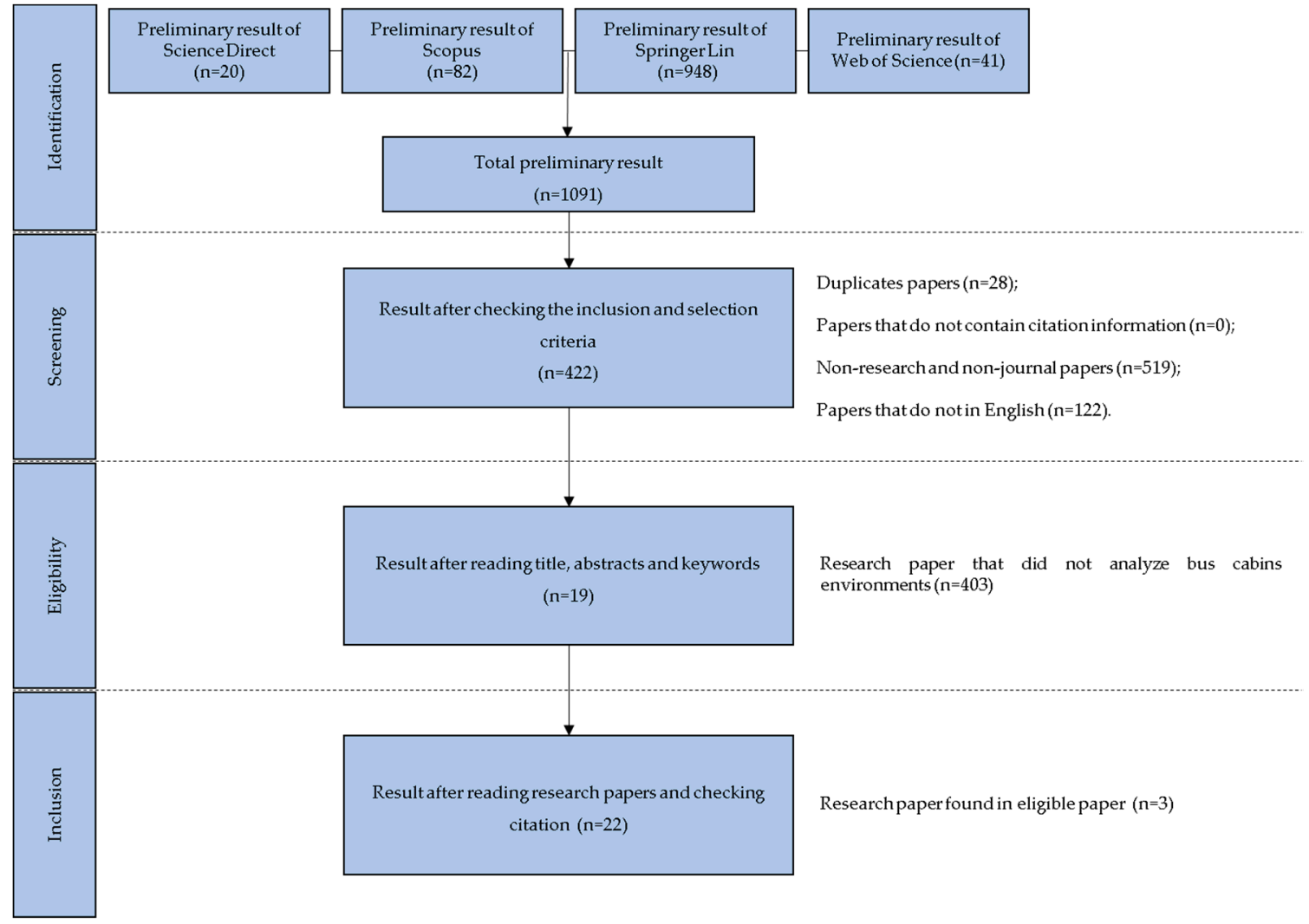

Figure 1. Number of papers on thermal comfort in buses found by this review.

Figure 1 presents the results of the four stages of the method used. In addition, it displays the criteria of inclusion, exclusion, and eligibility, with their respective results. Among the 22 research papers included, three $[10,46,47]$ were found because they cited one of the 19 eligible papers.

Table 4 displays the final result found in this research, presenting the names of the authors, titles of the papers, journals in which they were published, information related to the countries, the types of study developed (experimental and/or field research), the characterization of the samples, and the object of the studies selected. 
Table 4. Papers included in this review.

\begin{tabular}{|c|c|c|c|c|c|c|c|}
\hline References & Title & Journal & Year & Citation & Country & Type of Study & Environment \\
\hline Zhu et al. [11] & $\begin{array}{l}\text { Passenger comfort and ozone } \\
\text { pollution exposure in an } \\
\text { air-conditioned bus } \\
\text { microenvironment }\end{array}$ & $\begin{array}{c}\text { Environmental } \\
\text { Monitoring and } \\
\text { Assessment }\end{array}$ & 2020 & 0 & China & $\begin{array}{l}\text { Experimental and } \\
\text { field }\end{array}$ & Passengers' cabins \\
\hline Pala [48] & $\begin{array}{c}\text { Investigation of thermal } \\
\text { comfort for bus passengers } \\
\text { during a cooling test inside a } \\
\text { climatic chamber }\end{array}$ & $\begin{array}{c}\text { Journal of } \\
\text { Polytechnic-Politeknik } \\
\text { Dergisi }\end{array}$ & 2020 & 0 & Turkey & Experimental & Passengers' cabins \\
\hline $\begin{array}{l}\text { Hossam, Fouad, and } \\
\text { Abou-Zaid [9] }\end{array}$ & $\begin{array}{l}\text { Numerical investigation of } \\
\text { airflow patterns and thermal } \\
\text { comfort in a bus cabin }\end{array}$ & $\begin{array}{c}\text { Sae International } \\
\text { Journal of Passenger } \\
\text { Cars-Mechanical } \\
\text { Systems }\end{array}$ & 2020 & 0 & Egypt & Experimental & Passengers' cabins \\
\hline Zhang et al. [13] & $\begin{array}{l}\text { The threshold effects of bus } \\
\text { micro-environmental } \\
\text { exposures on passengers' } \\
\text { momentary mood }\end{array}$ & $\begin{array}{l}\text { Transportation } \\
\text { Research Part } \\
\text { D-Transport and } \\
\text { Environment }\end{array}$ & 2020 & 1 & China & Field & Passengers' cabins \\
\hline $\begin{array}{c}\text { Makowiec-Dabrowska } \\
\text { et al. [18] }\end{array}$ & $\begin{array}{l}\text { Climate conditions and } \\
\text { work-related fatigue among } \\
\text { professional drivers }\end{array}$ & $\begin{array}{l}\text { International Journal } \\
\text { of Biometeorology }\end{array}$ & 2019 & 7 & Poland & Field & Drivers' cabins \\
\hline Zhu et al. [14] & $\begin{array}{l}\text { Air quality and passenger } \\
\text { comfort in an air-conditioned } \\
\text { bus micro-environment }\end{array}$ & $\begin{array}{c}\text { Environmental } \\
\text { Monitoring and } \\
\text { Assessment }\end{array}$ & 2018 & 3 & China & Experimental & Passengers' cabins \\
\hline Velt and Daanen [15] & $\begin{array}{l}\text { Optimal bus temperature for } \\
\text { thermal comfort during a cool } \\
\text { day }\end{array}$ & Applied Ergonomics & 2017 & 15 & Netherlands & Field & Passengers' cabins \\
\hline Unal [49] & $\begin{array}{l}\text { An experimental study on a } \\
\text { bus air conditioner to } \\
\text { determine its conformity to } \\
\text { design and comfort } \\
\text { conditions }\end{array}$ & $\begin{array}{l}\text { Journal of Thermal } \\
\text { Engineering }\end{array}$ & 2017 & 5 & Turkey & Experimental & $\begin{array}{l}\text { Passengers' and } \\
\text { drivers' cabins }\end{array}$ \\
\hline
\end{tabular}


Table 4. Cont.

\begin{tabular}{|c|c|c|c|c|c|c|c|}
\hline References & Title & Journal & Year & Citation & Country & Type of Study & Environment \\
\hline Pala and Oz [31] & $\begin{array}{l}\text { An investigation of thermal } \\
\text { comfort inside a bus during } \\
\text { heating period within a } \\
\text { climatic chamber }\end{array}$ & Applied Ergonomics & 2015 & 34 & Turkey & Experimental & Passengers' cabins \\
\hline $\begin{array}{c}\text { Pimenta and Assuncao } \\
{[50]}\end{array}$ & $\begin{array}{l}\text { Thermal discomfort and } \\
\text { hypertension in bus drivers } \\
\text { and chargers in the } \\
\text { metropolitan region of Belo } \\
\text { Horizonte, Brazil }\end{array}$ & Applied Ergonomics & 2015 & 15 & Brazil & Field & $\begin{array}{l}\text { Drivers' and } \\
\text { chargers' cabins }\end{array}$ \\
\hline Ismail et al. [19] & $\begin{array}{l}\text { Relationship between thermal } \\
\text { comfort and driving } \\
\text { performance among } \\
\text { Malaysian bus driver }\end{array}$ & $\begin{array}{l}\text { ARPN Journal of } \\
\text { Engineering and } \\
\text { Applied Sciences }\end{array}$ & 2015 & 3 & Malaysia & Field & Drivers' cabins \\
\hline Ismail et al. [51] & $\begin{array}{l}\text { A descriptive analysis of } \\
\text { factors contributing to bus } \\
\text { drivers' performances while } \\
\text { driving: a case study in } \\
\text { Malaysia }\end{array}$ & $\begin{array}{c}\text { International Journal } \\
\text { of Automotive and } \\
\text { Mechanical } \\
\text { Engineering }\end{array}$ & 2015 & 16 & Malaysia & Field & Drivers' cabins \\
\hline $\begin{array}{l}\text { Assunção, Jardim, and } \\
\text { Medeiros [52] }\end{array}$ & $\begin{array}{l}\text { Voice complaints among } \\
\text { public transport workers in } \\
\text { the metropolitan region of } \\
\text { Belo Horizonte, Brazil }\end{array}$ & $\begin{array}{l}\text { Folia Phoniatrica et } \\
\text { Logopaedica }\end{array}$ & 2014 & 1 & Brazil & Field & $\begin{array}{l}\text { Drivers' and } \\
\text { chargers' cabins }\end{array}$ \\
\hline $\begin{array}{c}\text { Zhang, Zhou, and } \\
\text { Zhang [5] }\end{array}$ & $\begin{array}{c}\text { Evaluating bus transit } \\
\text { performance of Chinese cities: } \\
\text { developing an overall bus } \\
\text { comfort model }\end{array}$ & $\begin{array}{l}\text { Transportation } \\
\text { Research Part A: } \\
\text { Policy and Practice }\end{array}$ & 2014 & 22 & China & Field & Passengers' cabins \\
\hline Vollaro [10] & $\begin{array}{l}\text { Indoor climate analysis for } \\
\text { urban mobility buses: a CFD } \\
\text { model for the evaluation of } \\
\text { thermal comfort }\end{array}$ & $\begin{array}{l}\text { International Journal } \\
\text { of Environmental } \\
\text { Protection and Policy }\end{array}$ & 2013 & 10 & Italy & $\begin{array}{l}\text { Experimental and } \\
\text { field }\end{array}$ & Passengers' cabins \\
\hline
\end{tabular}


Table 4. Cont

\begin{tabular}{|c|c|c|c|c|c|c|c|}
\hline References & Title & Journal & Year & Citation & Country & Type of Study & Environment \\
\hline Lin et al. [53] & $\begin{array}{l}\text { Passenger thermal } \\
\text { perceptions, thermal comfort } \\
\text { requirements, and } \\
\text { adaptations in short- and } \\
\text { long-haul vehicles }\end{array}$ & $\begin{array}{l}\text { International Journal } \\
\text { of Biometeorology }\end{array}$ & 2010 & 35 & China & Field & Passengers' cabins \\
\hline $\begin{array}{l}\text { Zhu, Demokritou, and } \\
\text { Spengler [46] }\end{array}$ & $\begin{array}{c}\text { Experimental and numerical } \\
\text { investigation of } \\
\text { micro-environmental } \\
\text { conditions in public } \\
\text { transportation buses }\end{array}$ & $\begin{array}{l}\text { Building and } \\
\text { Environment }\end{array}$ & 2010 & 56 & United States & $\begin{array}{l}\text { Experimental and } \\
\text { field }\end{array}$ & Passengers cabins \\
\hline $\begin{array}{c}\text { Khamis Mansour et al. } \\
{[16]}\end{array}$ & $\begin{array}{l}\text { Development of novel control } \\
\text { strategy for multiple circuit, } \\
\text { rooftop bus air conditioning } \\
\text { system in hot humid countries }\end{array}$ & $\begin{array}{l}\text { Energy Conversion } \\
\text { and Management }\end{array}$ & 2008 & 25 & China & Experimental & Passengers cabins \\
\hline Shek and Chan. [17] & $\begin{array}{l}\text { Combined comfort model of } \\
\text { thermal comfort and air } \\
\text { quality on buses in Hong } \\
\text { Kong }\end{array}$ & $\begin{array}{l}\text { Science of the Total } \\
\text { Environment }\end{array}$ & 2008 & 50 & China & Field & Passengers cabins \\
\hline $\begin{array}{c}\text { Khamis Mansour et al. } \\
\text { [54] }\end{array}$ & $\begin{array}{l}\text { Development of a novel } \\
\text { control strategy for a } \\
\text { multiple-circuit roof-top bus } \\
\text { air-conditioning system in hot } \\
\text { humid countries }\end{array}$ & $\begin{array}{l}\text { International Journal } \\
\text { of Mechanical and } \\
\text { Materials Engineering }\end{array}$ & 2007 & 2 & China & Experimental & Passengers cabins \\
\hline Mui and Shek [47] & $\begin{array}{l}\text { Influence of in-tunnel } \\
\text { environment to in-bus air } \\
\text { quality and thermal condition } \\
\text { in Hong Kong }\end{array}$ & $\begin{array}{l}\text { Science of the Total } \\
\text { Environment }\end{array}$ & 2005 & 9 & China & Field & Passengers cabins \\
\hline Conceição et al. [55] & $\begin{array}{c}\text { Airflow around a passenger } \\
\text { seated in a bus }\end{array}$ & HVAC and R Research & 1997 & 16 & Portugal & Experimental & Passengers cabins \\
\hline
\end{tabular}




\subsection{Bibliometric Results}

The bibliometric analysis conducted in this paper seeks to present the general characteristics of the studies on thermal comfort conducted in bus cabins. The 22 papers selected by the adopted method were analyzed, through the script Bibliometrix [45] and the software R Project to generate graphs and tables and extract information concerning the authors, journals, countries, keywords, and year of publication.

Figure 2 displays the frequency graph of papers published per year on the theme of thermal comfort analysis in bus cabin environments.

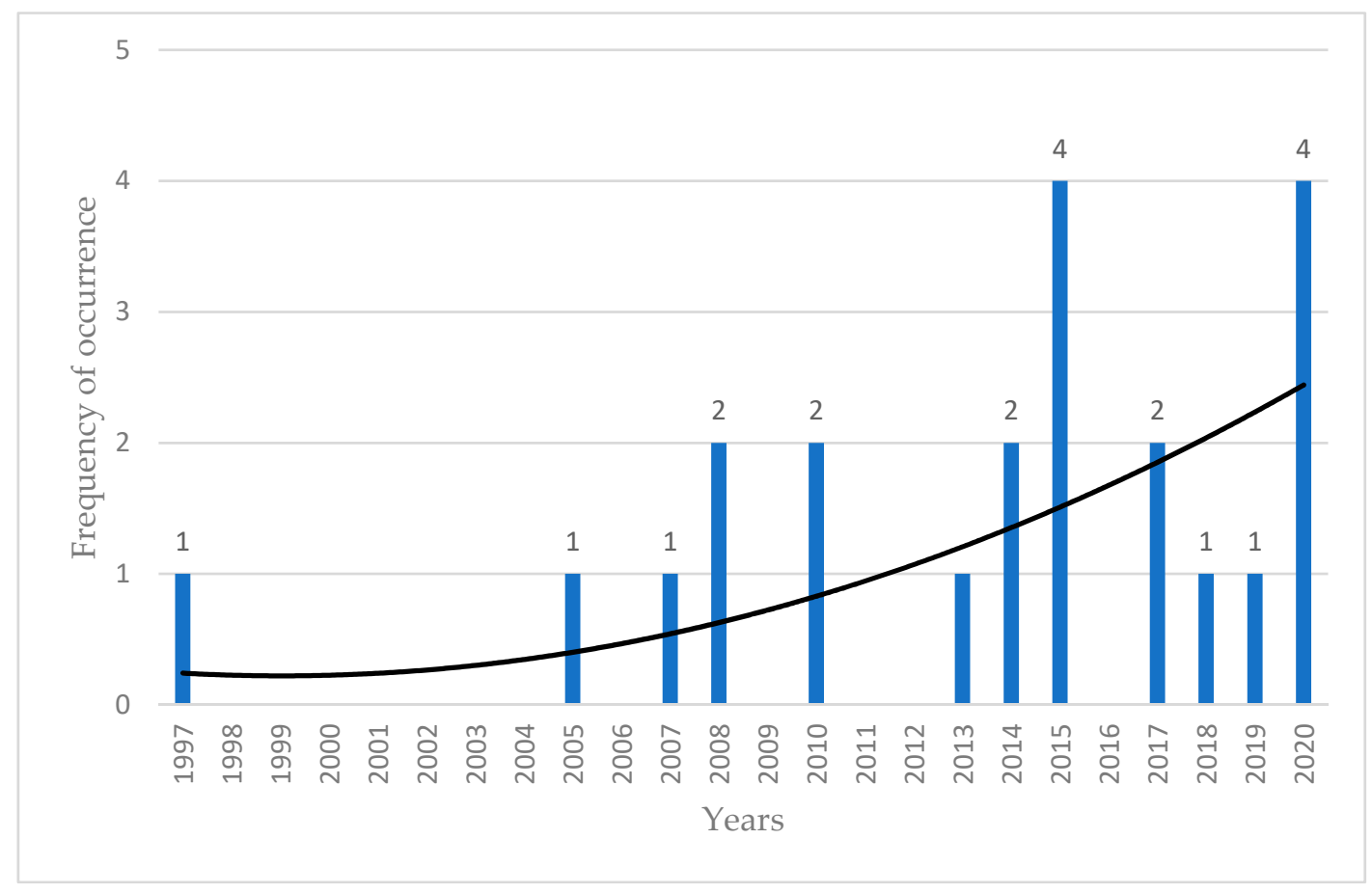

Figure 2. Annual scientific production of thermal comfort studies in bus cabin environments.

Overall, according to the tendency line (line in black) in Figure 2's graph, there has been a growing tendency in the number of publications over the years. This biased growth was driven after the year 2007 due to the increase in the number of publications per year, which increased from one to two articles on average and especially the years $2015[19,31,50,51]$ and $2020[9,11,13,48]$ stand out with four publications each. Therefore, it is noticeable that researchers in this knowledge area have been directing more attention to this environment, and that the significance of conducting thermal analyses in bus cabins has been growing.

Figure 2 also presents that the first publication related to thermal comfort in bus cabin environments was in 1997 [55], 27 years after Fanger's model was published. Conceição et al. [55] can be regarded as the gurus of the application of this knowledge area to the bus environment. In 1998, the significance of their work was acknowledged by its incorporation into ASHRAE Transactions [56]. It took eight years until the next publication [47] and, from that point on, other studies appeared, as the following paragraphs will detail.

It is worth mentioning that, in the studies detailed over the following paragraphs, the term thermal comfort is strongly related to climate conditions or may be correlated with a few of the six parameters presented in the methodology section. From that point, studies may investigate the conditions in the bus micro-climates and their authors may refer to the state of thermal comfort of the occupants.

Following a chronological order of the result of this investigation shown in Table 4, Conceição et al. [55] aimed to characterize the airflow around passengers and evaluated the thermal comfort conditions 
perceived by them in an experimental study. However, the authors planned four possible situations in which the occupants could find themselves in the bus, where they considered whether they had sunscreens or not and whether the seats were positioned in the aisle or by the windows. The contribution of this study was to distinguish the situations considered comfortable or uncomfortable by using the PMV-PPD indices of Fanger. The results revealed that the passengers on the aisle seats with the curtains closed felt comfortable, as shown by the indices of PMV $=-0.43$ and PPD $<10 \%$. The other situations simulated were disapproved: the passengers on the window seats with the curtains closed felt thermal discomfort due to cold, with a negative PMV, while passengers on the aisle or window seats with the curtains open felt thermal discomfort due to heat, with a positive PMV.

Later, in 2005, authors Mui and Shek [47] published an article aiming to study the exposure of bus passengers to significant air parameters $\left(\mathrm{CO}_{2}\right.$ and $\left.\mathrm{CO}\right)$ and a thermal environment (air temperature and relative humidity) when the buses traveled through tunnels in Hong Kong. In this study, the authors concluded that air-conditioned buses provided a better environment (air quality and temperature), and they were able to protect passengers from exposure to a dynamic and poor road environment along the tunnels. By contrast, the buses without air conditioning obtained better performance in air quality when entering and exiting tunnels (when compared to air-conditioned buses).

In 2007, Khamis Mansour et al. [54] published an article with the objective to develop a control strategy, through Fanger's PMV, for an automatic controller of the new multiple circuit air conditioning system and compared its performance with the conventional system. Thus, the comparison revealed that the proposed control strategy was able to introduce significant improvements in the thermal comfort and economic efficiency of buses.

In 2008, two publications were highlighted: one by authors Khamis Mansour et al. [16] which was similar to that described in 2007 by Khamis Mansour et al. [55], and the second, by Shek and Chan [17]. Authors Shek and Chan [17] proposed combined comfort models (thermal comfort and air quality) capable of indicating the comfort of traveling by bus. These models were developed through the correlation of objective parameters of air and thermal quality and the subjective sensations described by passengers (Fanger's PMV). However, the authors concluded that the thermal feeling had a more dominant position in the combined comfort level in both air-conditioned and non-air-conditioned buses.

The year 2010 achieved the same performance as in 2008 with two publications by Lin et al. [53] and Zhu, Demokritou, and Spengler [46]. Lin et al. [53] investigated the thermal comfort of passengers on buses and trains of short and long routes in Taiwan for over a year and a half including the comfort, sensation, and thermal preference of passengers, and found that higher temperatures, strong solar radiation, and low air speed are the main reasons for thermal discomfort. Furthermore, the authors found that neutral temperatures for short- and long-haul buses are $26.2{ }^{\circ} \mathrm{C}$ and $27.4{ }^{\circ} \mathrm{C}$; and the corresponding thermal comfort zones are between 22.4 and $28.9^{\circ} \mathrm{C}$ and 22.4 and $30.1^{\circ} \mathrm{C}$, respectively.

Zhu, Demokritou, and Spengler [46] used the 3D model of Computational Fluid Dynamics (CFD) to numerically examine the microclimate conditions of buses in terms of average age and average residual air life and held an experiment to monitor passengers' exposure to these conditions. However, the authors indicated that, for the used winter conditions, the thermal comfort range was found on the warmer side of the comfort zone recommended by ASHRAE 55.

Vollaro [10] in 2013 used Computational Fluid Dynamic (CFD, Fluent Inc., New York, NY, USA) software to numerically simulate the internal climate of urban buses, and later an experimental study was carried out in Italy to validate the model proposed by the authors in particular summer conditions. This proposal came to remedy the lack of standards for assessing and classifying the quality of the thermal environments in vehicles that, according to the authors, did not exist until now. As a result, the distribution of temperature and air speed around the seated and standing passengers was presented, and according to the authors, the simulation results were in accordance with those measured in the experiment.

Later Zhang, Zhou, and Zhang [5] developed a combined model of bus comfort that considers subjective and objective environmental parameters such as noise, vibration, thermal comfort, and the 
acceleration and experience of passengers. This way, they generated an applicable model with seven possible parameters that influence comfort in a bus, and with this information the authors estimated that the comfort of passengers on buses could improve by nearly $20 \%$ if the parameters of the proposed model were considered.

Still, in 2014, authors Assunção, Jardim, and Medeiros [52] innovated by studying the professionals working on buses. Aiming to investigate the prevalence of vocal health-related complaints by bus drivers and collectors in Brazil. The conclusion of this study demonstrated that there are risk factors (vibrations and thermal discomfort) positively associated with the role of the conductor and that justify interventions to promote vocal health.

The year 2015 had the highest number of publications in this domain of knowledge, with four publications by Pala and Oz [31], Pimenta and Assuncao [50], Ismail et al. [19] and Ismail et al. [51]. The work of Pala and Oz [31] in Turkey defined a test and calculation model to assess the thermal comfort of bus air conditioning, and subsequently compared the effects of the change parameters on the thermal comfort of passengers. With the support of an experimental procedure, the cited authors created a mathematical model that was developed to be used by automotive air conditioning engineers and scientists who work with thermal comfort as a human dimension.

Pimenta and Assuncao [50] evaluated the relationship between the perception of the temperature inside the bus and hypertension among public transportation workers in Brazil. The cited authors concluded that thermal discomfort was associated with a higher prevalence of hypertension in the two comfort categories considered: thermal discomfort of the disorders and unbearable, which were independently related to hypertension.

Ismail et al. [19] investigated the correlation between thermal comfort and the performance of Malaysian bus drivers throughout their journey. They concluded that there is a positive correlation between the variables of thermal comfort (temperature, relative humidity, and air speed) and the performance of drivers.

In his second work, Ismail et al. [51] presented the factors that contribute to the performance of bus drivers. As in their first publication, the authors carried out a field study and questioned Malaysian drivers about the interference they perceived in the following parameters: temperature, speed, relative humidity, and vibration. However, in light of the drivers' responses, the authors inferred that the cold air temperature or a lower relative humidity can lead to a better performance of these professionals, and the air speed did not affect the drivers' perception of their performance.

Two papers from 2017 were included in this investigation, Velt and Daanen [15] and Unal [49]. Velt and Daanen [15] investigated the thermal sensation and comfort of passengers in order to extend the distance covered with the same battery charge in electric buses during a cold day in the Netherlands. However, the thermal sensation was significantly related to the temperature of the bus, the insulation of the clothes, and the age. Based on these parameters, the temperature inside the bus corresponding to thermal comfort equaling zero and the thermal sensation equaling zero would have been $20.9 \pm 0.6^{\circ} \mathrm{C}$. This way, the authors concluded that a low bus temperature of $1.6^{\circ} \mathrm{C}$ during the given cold day would likely lead to less thermal discomfort and energy savings for electric buses.

Unal [49] developed an experimental study bus, in particular summer conditions in Turkey, to examine whether air conditioning systems meet the requirements for the design and the feeling of thermal comfort. Therefore, the author measured three parameters (temperature, speed, and relative air humidity) at various points of the bus, and with this he calculated the cooling load and the sensitive and latent heat gain for the occupants. Thus, he concluded that the buses must remain for $30 \mathrm{~min}$ with the air conditioning system on to reach an acceptable level of internal temperature before continuing their journey.

Zhu et al. [14] in 2018 investigated the passenger comfort and air pollution status of an air-conditioned bus in China and the results of a simulation indicated that reducing or adding air vents would shorten the time needed to achieve stable conditions and would either weaken the airflow or decrease the temperature in the cabin. 
Makowiec-Dabrowska et al. [18] in a field study carried out in Poland, investigated whether climatic parameters (temperature, air pressure, humidity, wind speed, and precipitation) are related to the perception of fatigue by bus drivers in two situations (monotonous route and heavy traffic). As a result, the authors inferred that the route of intense traffic results in more fatigue more than the monotonous route. In addition, significant correlations were found between wind speed and the symptoms of heavy eyelids, forgetfulness, eye strain, frequent blinking, and between ambient temperature and thirst, on the monotonous route. However, for the intense traffic route, the ambient temperature was correlated with the sensation of thirst, tiredness, and decision-making difficulty, and the wind speed was correlated with the sensation of thirst.

The year 2020 had the same performance as 2015 with four publications $[9,11,13,48]$. Hossam, Fouad, and Abou-Zaid [9] used computational fluid dynamics (CFD) and the PMV-PPD model to investigate three particular cases. In the first, the conditioning system vents in the buses were varied at four angles $\left(0^{\circ}, 15^{\circ}, 30^{\circ}\right.$, and $\left.45^{\circ}\right)$, in the second case, the authors chose the best vent angles and changed the air speed in two stages (from 1 to $2 \mathrm{~m} / \mathrm{s}$ and from 2 to $3 \mathrm{~m} / \mathrm{s}$ ), and the third investigated an air conditioning system in which the outlet was rectangular and fixed without the possibility of angulation. However, the vent angle of $30^{\circ}$ (PMV $=+0.3$ thermal neutrality and PPD $=5 \%$ thermally acceptable environment) and the speed of $3 \mathrm{~m} / \mathrm{s}$ were considered the best setting in terms of airflow and temperature around the passengers.

Zhu et al. [11] investigated the effects of air pollution and temperature distribution on passenger comfort in an air-conditioned bus in China. As a result, the authors inferred that the passengers were in an environment with poor air quality due to ozone from the outside air and were thermally uncomfortable due to the high temperature. According to the authors, the effect of this thermal discomfort can be minimized by adjusting the system's vents to an angle of $30^{\circ}$, the same angle recommended in the study by Hossam, Fouad, and Abou-Zaid [9].

Zhang et al. [13] performed a field study in China to examine the effects of micro-environmental exposure (noise, air quality, temperature, relative humidity, and passenger load) and buses on passengers' moods. The result of this field study indicated that the ideal exposure levels for these microenvironmental indicators in the passenger cabin are 0 to $65 \mathrm{~dB}$ for noise, 22 to $28{ }^{\circ} \mathrm{C}$ for air temperature, $41 \%$ to $50 \%$ for relative humidity, and 18 to 19 for passenger capacity.

In Turkey, Pala [48] conducted an experiment under controlled conditions in a climate chamber to assess the thermal comfort of passengers during a bus cooling process. In addition, the effects of rapid transient cooling conditions on the transfer of sensitive or latent heat from the body, on core and skin temperatures, and on thermal discomfort and sensation have been detailed. After $60 \mathrm{~min}$ of starting the bus' air conditioning system, the air temperature dropped from 40 to $28.8^{\circ} \mathrm{C}$ and the relative humidity had no significant changes rising from $41 \%$ to $47 \%$. The variation in the energy flow between the nucleus and the skin increased as the temperature dropped, since the body loses heat to the environment and, with this, the body generates heat in the nucleus and transmits to the skin to compensate the loss; thermal sensation dropped from -0.19 (thermal neutrality) to -4.063 (very cold) as the temperature dropped.

In this context, the most prominent authors in this knowledge area related to bus cabin environments are presented in Figure 3.

Figure 3 shows that the authors Abdullah, A.A.; Assunção, A.A.; Atikah Abdullah, S.N.; Deros, B.N.; Ismail, A.R.; Khamis, M.; Lei, L.; Pala, U.; Saqr, K.M.; Shek, K.W.; Wang, X.; Zhu, $\mathrm{X}$., with two works each, published the highest number of research papers in journals. However, as leading authors, Ismail, A.R.; Krames, M.; Pala, U.; Zhu, X. appear with two publications each, while Assunção, A.A. and Shek, K.M. published one paper as leading authors and another as co-authors. The other scholars listed are co-authors that participated in two publications. 


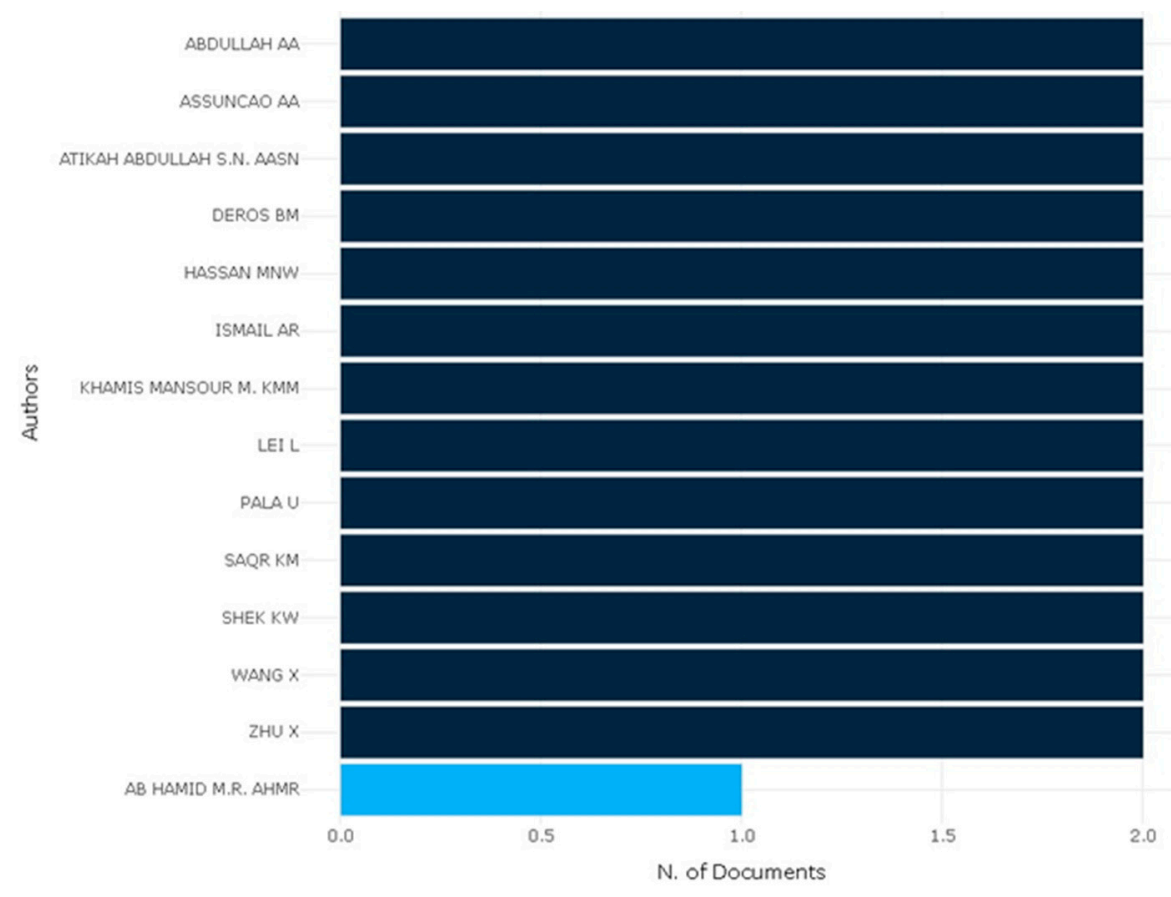

Figure 3. The most relevant authors of thermal comfort studies in bus cabin environments.

Moreover, it is worth pointing out that the works of Zhu, Demokritou, and Spengler [46] and Shek and Chan [17] received the most citations among the 22 papers selected in this review, with 56 and 50, respectively, (see Table 4) according to Google Scholar.

Table 5 displays the ten keywords with the highest occurrence in the thermal comfort studies in buses.

Table 5. Top 10 of the most relevant keywords of thermal comfort studies in bus cabin environments.

\begin{tabular}{cc}
\hline Keywords & Occurrences \\
\hline Thermal comfort & 11 \\
Bus & 4 \\
Numerical simulation & 3 \\
Thermal sensation & 2 \\
Air velocity & 2 \\
Bus air conditioning & 2 \\
Costing & 2 \\
Relative humidity & 2 \\
\hline
\end{tabular}

Table 5 shows that, of the 22 papers included in the review, 11 employ the term thermal comfort in their keywords. Moreover, it is obvious that the two terms with the highest occurrence in the table are related to the theme delimited by this research, which centered on thermal comfort in the bus. The other keywords appeared only once and, therefore, are not displayed in the table mentioned. Next, Table 6 presents the journals that published the most papers.

Table 6. Most relevant journals.

\begin{tabular}{cc}
\hline Journal & Paper \\
\hline Applied Ergonomics & 3 \\
Environmental Monitoring and Assessment & 2 \\
International Journal of Biometeorology & 2 \\
Science of the Total Environment & 2 \\
\hline
\end{tabular}


According to Table 6, the journal with the most publications within this knowledge area is Applied Ergonomics, with three research papers. The other sources, not displayed in the table, published one paper. They can be viewed in Table 4 .

\section{Discussion}

This section centers on the search for answers for the RQ's through reading, in their entirety, the papers included in this review employing the method adopted.

\section{1. $R Q_{1}$ : What Were the Approaches Adopted by Thermal Comfort Studies Conducted in Bus Cabins?}

The approaches assumed or investigated in the thermal comfort studies applied in bus cabin environments were identified in the general objective of each research included by this review. Table 7 shows the result of this proposed identification.

Table 7. Approaches adopted in the objectives of the studies included by this review.

\begin{tabular}{cccc}
\hline Approach & References & Total & $\%$ \\
\hline Thermal sensation & {$[5,9-11,13,14,18,31,46-50,52,53,55]$} & 16 & $73 \%$ \\
Productivity & {$[19,51]$} & 2 & $9 \%$ \\
Energy or fuel saving & {$[15-17,54]$} & 4 & $18 \%$ \\
\hline
\end{tabular}

According to Table 7, most thermal comfort studies in bus cabin environments focused on the thermal sensation aspect. Of the 16 research papers directed at the most investigated aspect, 12 analyzed only the passenger cabins [5,9-11,13,14,31,46-48,53,55], two observed only the drivers [18], one focused on passengers and drivers [49], and two sampled drivers and ticket collectors [50,52].

The two papers that addressed the productivity aspect are aligned with the drivers, who were questioned regarding the interference of thermal comfort in their driving performance [19,51]. They were two field studies that sought, subjectively, to correlate the six parameters employed in the models of thermal comfort with the performance of these workers, through five questions about each parameter.

Concerning the energy or fuel conservation aspect, Velt and Daanen [15] in their field study conducted in the Netherlands, sought to save energy in electric buses without compromising the feeling of well-being of the passengers. Khamis Mansour et al. [16,54] conducted an experiment and developed a control strategy for an air-conditioning system aiming to save fuel in Chinese buses without affecting the passengers' thermal comfort. Shek and Chan [17], through a field study in China, developed models that combined thermal comfort and air quality, elements that might be capable of optimizing air-conditioning control, maintaining an optimal balance between energy conservation and passenger satisfaction.

Overall, the energy and fuel economy approach is always accompanied by the well-being approach, seeing that saving fuel is pointless without providing a comfort level suitable for bus passengers.

\section{2. $R Q_{2}$ : What Thermal Comfort Parameters Were Investigated in the Studies That Analyzed Bus Cabins?}

Table 8 presents the thermal comfort parameters investigated by the studies included in this review.

Observing Table 8 , it is possible to note that the parameters air temperature and air velocity were widely employed in the analyses of thermal comfort in bus cabin environments. This occurrence is explained by the control of air-conditioning systems, which in general control the temperature and velocity of air to cool or heat the environment.

Moreover, of the 22 papers included in this review, eight $[5,9,15,16,31,48,53,54]$ analyzed the six parameters that are widely employed in the standard models of thermal comfort by ISO or ASHRAE [37,40]. It is worth pointing out that the table above only presents the parameters of this knowledge area, but these studies employ other variables, related to other types of comfort and the sociodemographic characteristics of the occupants. 
Table 8. Thermal comfort parameters considered in thermal comfort studies in bus cabins.

\begin{tabular}{|c|c|c|c|c|c|c|}
\hline \multirow{2}{*}{ References } & \multicolumn{6}{|c|}{ Thermal Comfort Parameters } \\
\hline & $\mathbf{t}_{\mathbf{a}}$ & $\mathbf{V}_{\mathbf{a}}$ & $t_{r m}$ & HR & $\mathbf{M}$ & $\mathbf{I}_{\text {clo }}$ \\
\hline Zhu et al. [11] & $\mathrm{x}$ & $x$ & & & & \\
\hline Pala [48] & $x$ & $x$ & $x$ & $x$ & $x$ & $x$ \\
\hline Hossam, Fouad, and Abou-Zaid [9] & $\mathrm{x}$ & $x$ & $x$ & $x$ & $x$ & $x$ \\
\hline Zhang et al. [13] & $x$ & $x$ & & & & \\
\hline Makowiec-Dabrowska et al. [18] & $x$ & $x$ & & & & \\
\hline Zhu et al. [14] & $\mathrm{x}$ & $x$ & $\mathrm{x}$ & & & \\
\hline Velt and Daanen [15] & $x$ & $x$ & $x$ & $x$ & $x$ & $x$ \\
\hline Unal [49] & $x$ & $x$ & & $x$ & & \\
\hline Pala and Oz [31] & $x$ & $x$ & $x$ & $x$ & $x$ & $x$ \\
\hline Pimenta and Assuncao [50] & $\mathrm{x}$ & & & & & \\
\hline Ismail et al. [19] & $x$ & $x$ & $\mathrm{x}$ & $\mathrm{x}$ & & $x$ \\
\hline Ismail et al. [51] & $x$ & $x$ & $x$ & $x$ & & $x$ \\
\hline Assunção, Jardim, and Medeiros [52] & $x$ & & & & & \\
\hline Zhang, Zhou, and Zhang [5] & $\mathrm{x}$ & $x$ & $x$ & $x$ & $x$ & $x$ \\
\hline Vollaro [10] & $x$ & $x$ & & & & \\
\hline Lin et al. [53] & $x$ & $x$ & $x$ & $x$ & $x$ & $x$ \\
\hline Zhu, Demokritou, and Spengler [46] & $x$ & $x$ & & $x$ & & \\
\hline Khamis Mansour et al. [16] & $x$ & $x$ & $x$ & $x$ & $x$ & $x$ \\
\hline Shek and Chan. [17] & $x$ & $x$ & & & & \\
\hline Khamis Mansour et al. [54] & $x$ & $x$ & $x$ & $x$ & $x$ & $x$ \\
\hline Mui and Shek [47] & $\mathrm{x}$ & & & $x$ & & \\
\hline Conceição et al. [55] & $x$ & $x$ & & & & \\
\hline
\end{tabular}

In the studies of Ismail et al. $[19,51]$, the environmental and personal parameters were not measured but rather presented as questions to the drivers and correlated with the driving activity through questionnaires. In the studies by Zhu et al. [14], Velt and Daanen [15] and Lin et al. [53], besides the measurable parameters listed in Table 8 , the occupants were asked regarding subjective votes, such as the thermal sensation vote, the thermal preference vote, and the thermal acceptability vote, through questionnaires.

Overall, knowing these votes in thermal comfort studies is relevant due to two reasons: first, to know the operating adaptive methods of the users in adapting themselves to uncomfortable situations; second, to assess the predictive models through the discrepancies between analytical values and real subjective values. In bus cabin environments, these votes served to understand the occupants' adaptive behavior in choice of preferred seats, opening and inclination angle of the air outlets of the ventilation and air-conditioning systems, opening or closure of curtains due to solar radiation, and choice of clothing $[14,15,53]$.

\section{3. $R Q_{3}$ : Besides Thermal Comfort Parameters, What Other Variables Were Analyzed by Thermal Comfort Studies Conducted in Bus Cabins?}

Table 9 exposes the types of comfort investigated along with thermal comfort in the studies conducted in bus cabins.

Table 9 shows that of the 22 research papers included in this review, 12 intended to assess only thermal comfort $[9,15,16,18,19,31,47,50,51,53,55,56]$. Moreover, in bus cabins, the comfort knowledge area "air quality" was the most investigated along with the thermal area, followed by the acoustic, acceleration, and lighting comfort types.

Air quality comfort, investigated in bus cabin environments, is usually linked to the concentration of pollutants and suspended particles that might be inhaled through breathing by the occupants of the environment. The concentrations of carbon monoxide and dioxide $\left(\mathrm{CO}\right.$ and $\left.\mathrm{CO}_{2}\right)$ are among the most examined pollutants $[17,47,48]$. However, the concentrations of ozone (O3) [11] and sulfur dioxide 
(SO2) have also been investigated previously. Particulate matter with diameters of $10 \mu \mathrm{m}[14,46]$, $2.5 \mu \mathrm{m}[13,46]$, and ultrafine $[17,46,47]$ represent the suspended pollutants analyzed so far.

Table 9. Types of comfort evaluated on thermal comfort studies in bus cabin environments.

\begin{tabular}{cc}
\hline References & Comfort Type \\
\hline Zhu et al. [11] & Air quality \\
Pala [48] & Not available \\
Hossam, Fouad, and Abou-Zaid [9] & Not available \\
Zhang et al. [13] & Air quality and acoustics \\
Makowiec-Dabrowska et al. [18] & Not available \\
Zhu et al. [14] & Air quality \\
Velt and Daanen [15] & Not available \\
Unal [49] & Not available \\
Pala and Oz [31] & Not available \\
Pimenta and Assuncao [50] & Acoustics, acceleration, and luminous \\
Ismail et al. [19] & Not available \\
Ismail et al. [51] & Not available \\
Assunção, Jardim, and Medeiros [52] & Acoustics and acceleration \\
Zhang, Zhou, and Zhang [5] & Acoustics and acceleration \\
Vollaro [10] & Not available \\
Lin et al. [53] & Not available \\
Zhu, Demokritou, and Spengler [46] & Air quality \\
Khamis Mansour et al. [16] & Not available \\
Shek and Chan. [17] & Air quality \\
Khamis Mansour et al. [54] & Not available \\
Mui and Shek [47] & Air quality \\
Conceição et al. [55] & Not available \\
\hline &
\end{tabular}

According to Shek and Chan [17], passengers of buses without air-conditioning felt uncomfortable or very uncomfortable regarding air quality and thermal comfort, whereas passengers who used air-conditioned buses were satisfied in both criteria. Moreover, thermal comfort surpassed air quality regarding the perception of passengers of buses without air-conditioning [17].

According to Zhu et al. [11], the front and inferior-back regions of air-conditioned buses were the most critical regarding ozone concentration, which can be aggravated if the doors remain open for longer than $20 \mathrm{~s}$ or the occupants are as close as possible to the bus floor. Mui and Shek [47] also investigated pollutant concentrations at different height levels inside the bus. They assessed different floors and concluded that the bottom floor is more conducive to the pollutants examined than the top floor.

Regarding the particulate matter of 2.5- $\mu$ m diameter, Zhang et al. [13] did not find solid results to prove a statistically-significant relationship between these materials and the passengers' mood or airborne diseases.

According to Zhu et al. [14], increasing or decreasing airflow did not alter the concentration of particulate matter $(10 \mu \mathrm{m})$, but it did change the passengers' perception of airflow and reduced the temperature of the bus cabins.

$\mathrm{Zhu}$, Demokritou, and Spengler [46] did not find intolerable concentration levels of CO, 10- $\mu \mathrm{m}$, 2.5- $\mu \mathrm{m}$, or ultrafine particulate matter inside air-conditioned buses. However, the high concentration of $\mathrm{CO}_{2}$, due to the lack of air change inside this closed environment, drew the authors' attention because of the high risk of air transmission of the Influenza virus.

\section{4. $R Q_{4}$ : What International Standards of Thermal Comfort Did the Studies that Analyzed the Thermal Conditions of Bus Cabins Follow?}

Table 10 displays the standards and models of thermal comfort employed in the studies conducted in bus cabins. 
Table 10. Standards and models employed in thermal comfort studies in bus cabins.

\begin{tabular}{ccc}
\hline References & Norms & Models \\
\hline Zhu et al. [11] & Not informed & Not informed \\
Pala [48] & ASHRAE 55 & Gagge Model \\
Hossam, Fouad, and Abou-Zaid [9] & ASHRAE 55 and ISO 7730 & PMV-PPD \\
Zhang et al. [13] & Not informed & Not informed \\
Makowiec-Dabrowska et al. [18] & Not informed & Not informed \\
Zhu et al. [14] & Not informed & Not informed \\
Velt and Daanen [15] & ISO 9886, ISO 10551, and ASHRAE 55 & PMV-PPD \\
Unal [49] & ASHRAE 55 and ASHRAE 62 & Adaptative \\
Pala and Oz [31] & ASHRAE 55 & Gagge Model \\
Pimenta and Assuncao [50] & Not informed & Not informed \\
Ismail et al. [19] & Not informed & Not informed \\
Ismail et al. [51] & Not informed & Not informed \\
Assunção, Jardim, and Medeiros [52] & Not informed & Not informed \\
Zhang, Zhou, and Zhang [5] & Not informed & PMV-PPD \\
Vollaro [10] & Not informed & Not informed \\
Lin et al. [53] & ASHRAE 55 & PMV-PPD \\
Zhu, Demokritou, and Spengler [46] & ASH 10551, ISO 14505-3, and ISSO 7726 & Not informed \\
Khamis Mansour et al. [16] & ASHRAE 55 & PMV-PPD \\
Shek and Chan. [17] & ASHRAE 55 & Not informed \\
Khamis Mansour et al. [54] & Not informed & PMV-PPD \\
Mui and Shek [47] & ISO 7730 and ASHRAE 55 & Not informed \\
Conceição et al. [55] & & PMV-PPD \\
\hline
\end{tabular}

Table 10 shows that the main international standards of thermal comfort (ISO and ASHRAE) were employed in a few studies, whereas it was not possible to identify the standards used by others. Thus, ASHRAE 55 was present in ten studies $[9,15-17,31,46,48,49,54,55]$ and can be considered the most employed in bus cabin environments.

Lin et al. [53] were the only authors to employ the ISO 14505-3 standard, one of the four belonging to the ISO 14505 series linked to vehicular thermal comfort. This ISO standard can be utilized in any vehicle type, including buses, and applied to passengers and drivers.

As discussed in Section 4.2, three studies questioned bus occupants regarding subjective parameters or sensation, preference, and thermal acceptability votes. Velt and Daanen [15] and Lin et al. [53] employed ISO 10551, which provides guidelines for subjective questions to occupants about the mentioned votes.

Despite these cited findings, at the end of the analysis of the studies included in this review, it was not possible to find a study that questioned any point of any of the standards linked to thermal comfort that applied to bus cab environments.

\section{5. $R Q_{5}$ : What Standard Models of Thermal Comfort Were Employed to Assess the Bus Cabins?}

Table 10 displays the studies conducted in bus cabins that employed standard models of thermal comfort. Thus, it is possible to observe that Fanger's Predicted Mean Vote-Predicted Percentage Dissatisfied (PMV-PPD) model, present in the ISO 7730 and ASHRAE 55 standards, was the most employed. Moreover, Gagge's model was utilized in two studies $[31,48]$ and the adaptive model in only one [49].

Of the studies that intended to assess only the thermal comfort in bus cabins (see Table 9), six $[10,16,18,19,51,54]$ did not specify or did not work with standard models but they remain relevant since an article is usually a summary of a larger research and many things are not mentioned in that summary or aimed to evaluate microclimate conditions in the bus cabins where the parameters of thermal comfort were not used in their amplitude. Moreover, of the studies that analyzed the comfort of drivers [18,19,49-52], only Unal [49] employed a standard model to assess the drivers' cabins. 
Among the papers, eight investigated all six parameters (see Table 8) and worked with a standard model (see Table 10) of thermal comfort, discovering the temperature ranges of thermal comfort and neutrality of the cabins. Lin et al. [53] concluded that, in air-conditioned buses and trains with short and long routes, the indoor air temperature for a sensation of thermal neutrality was 26.2 and $27.4{ }^{\circ} \mathrm{C}$, and the zones for thermal comfort ranged from 22.4 to $28.9{ }^{\circ} \mathrm{C}$ and 22.4 to $30.1{ }^{\circ} \mathrm{C}$, respectively.

According to Hossam, Fouad, and Abou-Zaid [9], among the projected scenarios of air outlet angles of the air-conditioning system in their experimental study, an air temperature of $23^{\circ} \mathrm{C}$ and air velocity of $0.3 \mathrm{~m} / \mathrm{s}$ provided the best performance with PMV $=+0.2$ (neutral) and PPD $=5 \%$ dissatisfied. Velt and Daanen [15] found that a range of indoor air temperature of $20.9 \pm 0.6^{\circ} \mathrm{C}$ corresponded to a comfort zone for electrical buses in cold climates. Finally, Khamis Mansour et al. [16] developed an air-conditioning control system capable of reducing fuel consumption that would maintain an indoor temperature of $25^{\circ} \mathrm{C}$, whose PMV would be -0.25 (neutral) and PPD $8 \%$ dissatisfied.

Overall, this review did not find reports that assessed the models' assertiveness or the proposition of a specific thermal comfort model for this environment, and the studies directed at passenger cabins were more based on standards than the ones directed at driver cabins.

\section{Conclusions}

Investigating comfort in buses involves a series of aspects. Among them, thermal comfort has been drawing more attention partly due to the time that people spend on vehicles and the search for comfortable mobility. Despite that, this investigation identified no papers that summarized published studies about the bus cabin environment. Without diminishing the contributions of the studies found in this systematic literature review, this investigation sought to meet the general objective of reviewing the thermal comfort studies applied to bus cabins in order to answer five research questions linked to the specific objectives.

However, examining the 22 research papers included in this review revealed that thermal analyses in buses started 27 years after the publication of Fanger's PMV-PPD model and that the drivers' thermal condition was only analyzed in 2014. Moreover, it became evident that more publications focus on the passengers than on the workers of this environment, which can be seen as an opportunity for future research to expand the knowledge related to this specific environment with research aimed at drivers.

In general, the current state of the art regarding the thermal comfort of bus cabin environments is inconsistent in terms of methodological procedures, especially with regard to the survey of parameters, the use of current standards, and standardized modeling of thermal comfort. There was a lot of variation in the experimental and field protocols with the widely disseminated theorists and, moreover, it was not possible to find a study that evaluated the consistency of the results of the standardized analytical models with the subjective values questioned to the occupants of that specific environment.

The review of the papers selected also revealed that the studies focusing on passengers have better theoretical bases than the ones conducted with drivers regarding the objective and subjective parameters measured, the utilization of international standards, and the utilization of standard models of thermal comfort found in the literature. Therefore, it is possible to infer that these points observed are opportunities to expand the analysis of thermal comfort in buses for future studies.

Regarding the approach methods of the thermal comfort studies in buses, the review found that more works correlate thermal sensation with the well-being, health, and security of the occupants than concerning driver productivity or fuel economy in buses. Therefore, there is a lack of studies that correlate the drivers' thermal comfort with their driving performance or their economic behavior, among other opportunities for future research.

The comfort inherent to air quality has been increasingly more analyzed along with thermal comfort in bus cabins. However, of the 22 articles included, four of them investigated acoustic comfort, three investigated acceleration comfort, and a single article investigated luminous comfort. Besides, the studies that analyzed air quality revealed that closed cabins are more conducive to the transmission 
of respiratory diseases due to inefficient indoor air change and that the critical regions of pollutant concentration are related to the height level of the cabin floor and the front part of the bus. In this context, there are opportunities for future studies with the possibility of analyzing ergonomic and vibration comfort along with thermal comfort in buses.

Finally, the review identified an impasse in the choice of the best environment for transportation between buses with or without air-conditioning, considering the concentration of pollutants investigated and present in their interior. For certain pollutants and particulate matter, it is better to maintain the bus closed as much as possible; for others, like $\mathrm{CO}_{2}$, a more open environment entails higher air quality. However, the literature recommends an open environment, seeing that the $\mathrm{CO}_{2}$ generated by the occupants' breathing may indicate whether the air is saturated and the need for air change in order to maintain a healthy environment, which presents fewer risks of transmission of viral respiratory diseases.

Author Contributions: Conceptualization, M.d.N.A.; methodology, M.d.N.A.; software, M.d.N.A.; formal analysis, M.d.N.A., A.A.d.P.X., and A.O.M.; writing—original draft preparation, M.d.N.A.; writing-review and editing, M.d.N.A. and A.O.M.; supervision, A.A.d.P.X. and A.O.M.; project administration, A.A.d.P.X. and A.O.M.; funding acquisition, M.d.N.A. All authors have read and agreed to the published version of the manuscript.

Funding: This research received no external funding.

Conflicts of Interest: The authors declare no conflict of interest.

\section{References}

1. Prakash, N.K.U.; Bhuvaneswari, S.; Kumar, M.R.; Lankesh, S.; Rupesh, K. A study on the prevalence of indoor mycoflora in air conditioned buses. Microbiol. Res. J. Int. 2014, 4, 282-292. [CrossRef]

2. Nguyen-Phuoc, D.Q.; Currie, G.; De Gruyter, C.; Young, W. Congestion relief and public transport: An enhanced method using disaggregate mode shift evidence. Case Stud. Transp. Policy 2018, 6, 518-528. [CrossRef]

3. Nguyen-Phuoc, D.Q.; Currie, G.; De Gruyter, C.; Kim, I.; Young, W. Modelling the net traffic congestion impact of bus operations in Melbourne. Transp. Res. Part A Policy Pract. 2018, 117, 1-12. [CrossRef]

4. Nguyen, T.; NguyenDinh, N.; Lechner, B.; Wong, Y.D. Insight into the lateral ride discomfort thresholds of young-adult bus passengers at multiple postures: Case of Singapore. Case Stud. Transp. Policy 2019, 7, 617-627. [CrossRef]

5. Zhang, K.; Zhou, K.; Zhang, F. Evaluating bus transit performance of Chinese cities: Developing an overall bus comfort model. Transp. Res. Part A Policy Pract. 2014, 69, 105-112. [CrossRef]

6. Morton, C.; Caulfield, B.; Anable, J. Customer perceptions of quality of service in public transport: Evidence for bus transit in Scotland. Case Stud. Transp. Policy 2016, 4, 199-207. [CrossRef]

7. Lai, W.-T.; Chen, C.-F. Behavioral intentions of public transit passengers-The roles of service quality, perceived value, satisfaction and involvement. Transp. Policy 2011, 18, 318-325. [CrossRef]

8. Barabino, B.; Eboli, L.; Mazzulla, G.; Mozzoni, S.; Murru, R.; Pungillo, G. An innovative methodology to define the bus comfort level. Transp. Res. Procedia 2019, 41, 461-470. [CrossRef]

9. Hossam, M.; Fouad, M.; Abou-Zaid, A. Numerical Investigation of Airflow Patterns and Thermal Comfort in a Bus Cabin. Sae Int. J. Passeng. Cars-Mech. Syst. 2020, 13, 145-156. [CrossRef]

10. De Lieto Vollaro, R. Indoor climate analysis for urban mobility buses: A CFD model for the evaluation of thermal comfort. Int. J. Environ. Prot. Policy 2013, 1, 1-8. [CrossRef]

11. Zhu, X.; Lei, L.; Han, J.; Wang, P.; Liang, F.; Wang, X. Passenger comfort and ozone pollution exposure in an air-conditioned bus microenvironment. Environ. Monit. Assess. 2020, 192. [CrossRef] [PubMed]

12. Fanger, P.O. Thermal Comfort. Analysis and Applications in Environmental Engineering; Danish Technical Press: Copenhagen, Denmark, 1970.

13. Zhang, L.; Zhou, S.; Kwan, M.-P.; Chen, F.; Dai, Y. The threshold effects of bus micro-environmental exposures on passengers' momentary mood. Transp. Res. Part D-Transp. Environ. 2020, 84. [CrossRef]

14. Zhu, X.; Lei, L.; Wang, X.; Zhang, Y. Air quality and passenger comfort in an air-conditioned bus micro-environment. Environ. Monit. Assess. 2018, 190. [CrossRef]

15. Velt, K.B.; Daanen, H.A.M. Optimal bus temperature for thermal comfort during a cool day. Appl. Ergon. 2017, 62, 72-76. [CrossRef] 
16. Mansour, M.K.; Musa, M.N.; Hassan, M.N.W.; Saqr, K.M. Development of novel control strategy for multiple circuit, roof top bus air conditioning system in hot humid countries. Energy Convers. Manag. 2008, 49, 1455-1468. [CrossRef]

17. Shek, K.W.; Chan, W.T. Combined comfort model of thermal comfort and air quality on buses in Hong Kong. Sci. Total Environ. 2008, 389, 277-282. [CrossRef] [PubMed]

18. Makowiec-Dabbrowska, T.; Gadzicka, E.; Siedlecka, J.; Szyjkowska, A.; Viebig, P.; Kozak, P.; Bortkiewicz, A. Climate conditions and work-related fatigue among professional drivers. Int. J. Biometeorol. 2019, 63, 121-128. [CrossRef]

19. Ismail, A.R.; Abdullah, S.A.; Abdullah, A.A.; Deros, B.M. Relationship between thermal comfort and driving performance among Malaysian bus driver. ARPN J. Eng. Appl. Sci. 2015, 10, 7406-7411.

20. World Health Organization. WHO Announces COVID-19 Outbreak a Pandemic n.d. Available online: http://www.euro.who.int/en/health-topics/health-emergencies/coronavirus\%0Acovid19/news/news/2020/3/ who-announces-covid-19-outbreak-a-pandemic (accessed on 10 October 2020).

21. Nishiura, H.; Oshitani, H.; Kobayashi, T.; Saito, T.; Sunagawa, T.; Matsui, T.; Wakita, T.; Covid, M.; Suzuki, M. Closed environments facilitate secondary transmission of coronavirus disease 2019 (COVID-19). MedRxiv 2020. [CrossRef]

22. Lajunen, A.; Yang, Y.; Emadi, A. Review of Cabin Thermal Management for Electrified Passenger Vehicles. IEEE Trans. Veh. Technol. 2020, 69, 6025-6040. [CrossRef]

23. Filipe, P.; Broday, E.E.; Augusto, A.; Xavier, D.P. Thermal Comfort Applied in Hospital Environments: A Literature Review. Appl. Sci. 2020, 10, 7030. [CrossRef]

24. Peeters, L.; De Dear, R.; Hensen, J.; D’haeseleer, W. Thermal comfort in residential buildings: Comfort values and scales for building energy simulation. Appl. Energy 2009, 86, 772-780. [CrossRef]

25. Rupp, R.F.; Vásquez, N.G.; Lamberts, R. A review of human thermal comfort in the built environment. Energy Build. 2015, 105, 178-205. [CrossRef]

26. Alahmer, A.; Mayyas, A.; Mayyas, A.A.; Omar, M.A.; Shan, D. Vehicular thermal comfort models; A comprehensive review. Appl. Therm. Eng. 2011, 31, 995-1002. [CrossRef]

27. Djongyang, N.; Tchinda, R.; Njomo, D. Thermal comfort: A review paper. Renew. Sustain. Energy Rev. 2010, 14, 2626-2640. [CrossRef]

28. Yao, R.; Li, B.; Liu, J. A theoretical adaptive model of thermal comfort-Adaptive Predicted Mean Vote (aPMV). Build. Environ. 2009, 44, 2089-2096. [CrossRef]

29. Croitoru, C.; Nastase, I.; Bode, F.; Meslem, A.; Dogeanu, A. Thermal comfort models for indoor spaces and vehicles-Current capabilities and future perspectives. Renew. Sustain. Energy Rev. 2015, 44, 304-318. [CrossRef]

30. Simion, M.; Socaciu, L.; Unguresan, P. Factors which Influence the Thermal Comfort Inside of Vehicles. Energy Procedia 2016, 85, 472-480. [CrossRef]

31. Pala, U.; Oz, H.R. An investigation of thermal comfort inside a bus during heating period within a climatic chamber. Appl. Ergon. 2015, 48, 164-176. [CrossRef]

32. Broday, E.E.; Ruivo, C.R.; Gameiro da Silva, M. The use of Monte Carlo method to assess the uncertainty of thermal comfort indices PMV and PPD: Benefits of using a measuring set with an operative temperature probe. J. Build. Eng. 2020, 101961. [CrossRef]

33. Das Neves Almeida, M.; de Paula Xavier, A.A.; Michaloski, A.O.; Soares, A.L. Thermal Comfort in Bus Cabins: A Review of Parameters and Numerical Investigation. In Occupational and Environmental Safety and Health II; Springer: Berlin/Heidelberg, Germany, 2020; pp. 499-506.

34. Enescu, D. A review of thermal comfort models and indicators for indoor environments. Renew. Sustain. Energy Rev. 2017, 79, 1353-1379. [CrossRef]

35. ISO 10551, I.S.O. Ergonomics of the Thermal Environment-Assessment of the Influence of the Thermal Environment Using Subjective Judgement Scales; International Standard Organization: Geneva, Switzerland, 1995.

36. ISO 7726, I.S.O. Ergonomics of the Thermal Environment-Instruments for Measuring Physical Quantities; International Standard Organization: Geneva, Switzerland, 1998.

37. EN ISO 7730, I.S.O. Ergonomics of the Thermal Environment. Analytical Determination and Interpretation of Thermal Comfort Using Calculation of the PMV and PPD Indices and Local Thermal Comfort Criteria; International Standard for Organization: Geneva, Switzerland, 2005.

38. ISO 8996, I.S.O. Ergonomics of the Thermal Environment-Determination of Metabolic Rate; International Standard Organization: Geneva, Switzerland, 2004. 
39. EN ISO 9920, I.O.S. Ergonomics of the Thermal Environment-Estimation of thermal Insulation and Water Vapor Resistance of a Clothing Ensemble; International Organization for Standardization: Geneva, Switzerland, 2009.

40. ASHRAE-55. Thermal Environmental Conditions for Human Occupancy; American Society of Heating, Refrigerating and Air-Conditioning: Atlanta, GA, USA, 2004; Volume 58.

41. ISO 14505-1, I.S.O. Ergonomics of the Thermal Environment-Evaluation of Thermal Environments in Vehicles-Part 1: Principles and Methods for Assessment of Thermal Stress; International Standard Organization: Geneva, Switzerland, 2007.

42. ISO 14505-2, I.S.O. Ergonomics of the Thermal Environment-Evaluation of Thermal Environments in Vehicles-Part 2: Determination of Equivalent Temperature; International Standard Organization: Geneva, Switzerland, 2006.

43. ISO 14505-3, I.S.O. Ergonomics of the Thermal Environment-Evaluation of Thermal Environments in Vehicles-Part 3: Evaluation of Thermal Comfort Using Human Subjects; International Standard Organization: Geneva, Switzerland, 2006.

44. Moher, D.; Liberati, A.; Tetzlaff, J.; Altman, D.G.; Group, P. Preferred reporting items for systematic reviews and meta-analyses: The PRISMA statement. PLoS Med. 2009, 6, e1000097. [CrossRef] [PubMed]

45. Aria, M.; Cuccurullo, C. bibliometrix: An R-tool for comprehensive science mapping analysis. J. Informetr. 2017, 11, 959-975. [CrossRef]

46. Zhu, S.; Demokritou, P.; Spengler, J. Experimental and numerical investigation of micro-environmental conditions in public transportation buses. Build. Environ. 2010, 45, 2077-2088. [CrossRef] [PubMed]

47. Mui, K.W.; Shek, K.W. Influence of in-tunnel environment to in-bus air quality and thermal condition in Hong Kong. Sci. Total Environ. 2005, 347, 163-174. [CrossRef] [PubMed]

48. Pala, U. Investigation of Thermal Comfort for Bus Passengers During a Cooling Test Inside a Climatic Chamber. J. Polytech. Politek. Derg. 2020, 23, 547-555. [CrossRef]

49. Unal, S. An experimental study on a bus air conditioner to determine its conformity to design and comfort conditions. J. Therm. Eng. 2017, 3, 1089-1101. [CrossRef]

50. Pimenta, A.M.; Assuncao, A.A. Thermal discomfort and hypertension in bus drivers and chargers in the metropolitan region of Belo Horizonte, Brazil. Appl. Ergon. 2015, 47, 236-241. [CrossRef]

51. Ismail, A.R.; Atikah Abdullah, S.N.; Abdullah, A.A.; Deros, B.M. A descriptive analysis of factors contributing to bus drivers' performances while driving: A case study in Malaysia. Int. J. Automot. Mech. Eng. 2015, 11, 2430-2437. [CrossRef]

52. Assunção, A.; Jardim, R.; De Medeiros, A.; Assuncao, A.; Jardim, R.; De Medeiros, A. Voice complaints among public transport workers in the metropolitan region of belo horizonte, Brazil. Folia Phoniatr. Logop. 2014, 65, 266-271. [CrossRef]

53. Lin, T.-P.; Hwang, R.-L.; Huang, K.-T.; Sun, C.-Y.; Huang, Y.-C. Passenger thermal perceptions, thermal comfort requirements, and adaptations in short- and long-haul vehicles. Int. J. Biometeorol. 2010, 54, 221-230. [CrossRef]

54. Khamis Mansour, M.; Musa, M.H.; Hassan, M.N.W.; Abdullah, H.; Saqr, K.M. Development of a novel control strategy for a multiple-circuit roof-top bus air-conditioning system in hot humid countries. Int. J. Mech. Mater. Eng. 2007, 2, 200-211. [CrossRef]

55. Conceição, E.Z.E.; Silva, M.C.G.; Viegas, D.X. Airflow around a passenger seated in a bus. HVAC R Res. 1997, 3, 311-323. [CrossRef]

56. Conceicao, E.Z.E.; Silva, M.C.G.; Viegas, D.X. Airflow around a passenger seated in a bus. In Proceedings of the ASHRAE Transactions, San Francisco, CA, USA, 18-21 January 1998; Volume 104, p. 628.

Publisher's Note: MDPI stays neutral with regard to jurisdictional claims in published maps and institutional affiliations.

(C) 2020 by the authors. Licensee MDPI, Basel, Switzerland. This article is an open access article distributed under the terms and conditions of the Creative Commons Attribution (CC BY) license (http://creativecommons.org/licenses/by/4.0/). 